\title{
First report of two synchronous but separately placed intramedullary angiolipomas located in the dorsal spine causing progressive compressive myelopathy: management strategies and outcome review
}

\author{
Guru Dutta Satyarthee ${ }^{1}$, Mehar Tej Burgula ${ }^{1}$ \\ 1 Department of Neurosurgery, Neurosciences Centre, \\ AlIMS New, INDIA
}

\begin{abstract}
Spinal angiolipoma is a benign lesion and presents with compressive myelopathy. Typically, it is located in epidural compartment. However, intramedullary angiolipoma is extremely uncommon, and till date only eight cases are reported in the literature and all reported cases had isolated solitary lesion. Authors report an interesting case of intramedullary spinal angiolipoma (ISAL) in a - 48- years male, presented with compressive myelopathy, magnetic resonance imaging study revealed presence of two separate angiolipomas, which were located at D8-D9 and D10-D12 vertebral levels respectively, underwent successful near total surgical resection with good neurological outcome. Current case represents first of its kind in the western literature. Management of such rare pathology along with pertinent literature is briefly discussed.
\end{abstract}

\section{INTRODUCTION}

Angiolipoma is a rare benign tumour most commonly found in the subcutaneous tissue of the trunk and extremities but other sites are also reported. [1] Histopathologically, it consists of mature fatty tissue interspersed with abnormal vascular elements. [2]. Spinal angiolipoma represent a distinct clinical and pathological entity, which account for approximately $0.04-1.2 \%$ of all spinal axis tumours. [3]. Spinal angiolipoma is mostly located in the epidural space and accounting for 2-3\% of spinal tumours. Only eight ceases of intramedullary lipoma are reported in literature. [4-10]. Due to rarity of lesion, these cases are usually missed as differential causes of compressive myelopathy, which have good prognosis following early surgical resection. Authors report a case of intradural spinal angiolipoma (ISAL), which was located in intramedullary- subpial located, who underwent successful surgical excision with good neurological recovery in the postoperative period.

\section{CASE ILLUSTRATION}

A 48 -year- male presented to our neurosurgical outpatient services with complaint of progressive spastic paraparesis for last two years. He also noticed tingling and numbness in involving trunk below

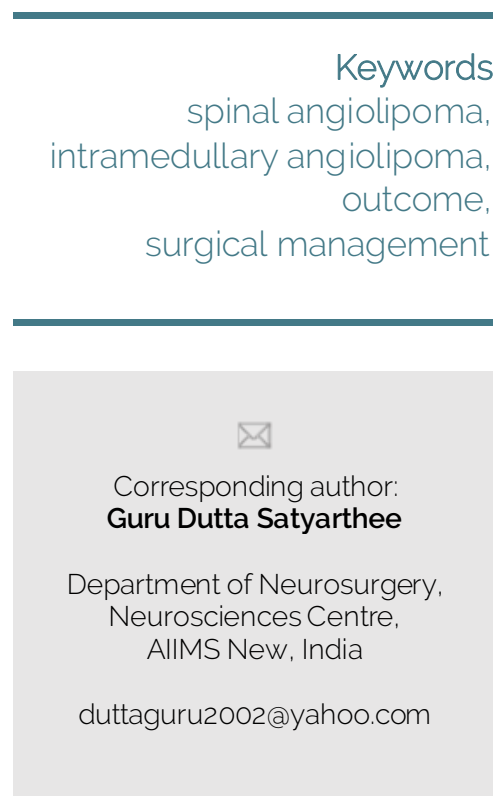

Copyright and usage. This is an Open Access article, distributed under the terms of the Creative Commons Attribution Non-Commercial No Derivatives License (https://creativecommons org/licenses/by-nc-nd/4.0/) which permits noncommercial re-use, distribution, and reproduction in any medium, provided the original work is unaltered and is properly cited.

The written permission of the Romanian Society of Neurosurgery must be obtained for commercial re-use or in order to create a derivative work.

ISSN online 2344-4959

(c) Romanian Society of Neurosurgery

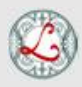

First published March 2019 by London Academic Publishing www.lapub.co.uk 
umbilicus and both lower limbs. He had no associated history of diabetes mellitus, hypertension, coronary artery disease or pulmonary tuberculosis. Examination on admission, revealed healthy male with vital stable, had scissoring gait, increased tone with motor power of $4 / 5$ in bilateral lower limbs along with graded sensory loss below the level D10 dermatomes, which was comparatively more marked on left side. The deep tendon jerks were brisk with ill sustained patellar and ankle clonus with plantars was extensor response bilaterally.

MR Imaging of the spine revealed, presence of two separate intradural intramedullary mass lesions located at D8 to D9 level and D10 to D12 levels (Fig1), showing heterogeneous hyper- intense signals on T1 and T2 weighted image, showing with characteristics suggestive of angiolipomas. Patient was diagnosed to two separate D8-D10 and D10D12 level spinal angiolipoma (Fig-2, 3). He was advised for surgical management with intraoperative electrophysiological monitoring.

He was taken up for surgery in prone position
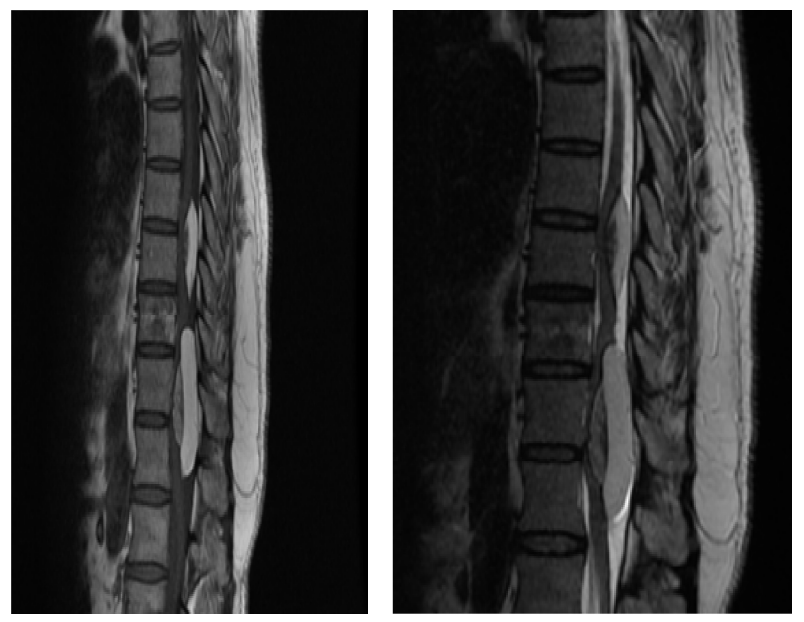

under general anaesthesia, intraoperative level was localized with image intensifiers, and underwent D7L1 laminectomy, after laminectomy bulging of dura sac was noted, however, no epidural mass was observed. But dura was bulging. Midline durotomy was carried out; two separate lesions were noted at D8-D9 and D10- D12 levels respectively. Eccentrically placed mass was observed, after pial incision, pale coloured fat with larger branching vessels were noted, near total decompression with Cusa was carried out. The lesions were intra medullary in location containing lipomatous mass interspersed with dilated veins. Subtotal excision was carried out as further resection attempt led to electrophysiological abnormality. After securing hemostasis, primary dural closure was carried out and the wound was closed in layers. He tolerated surgical procedure well with no appearance of fresh neurological deficits and discharged on fifth day following surgery. At last follow-up six months after surgery, has mild improvement in motor power, however sensory deficit was persisting.
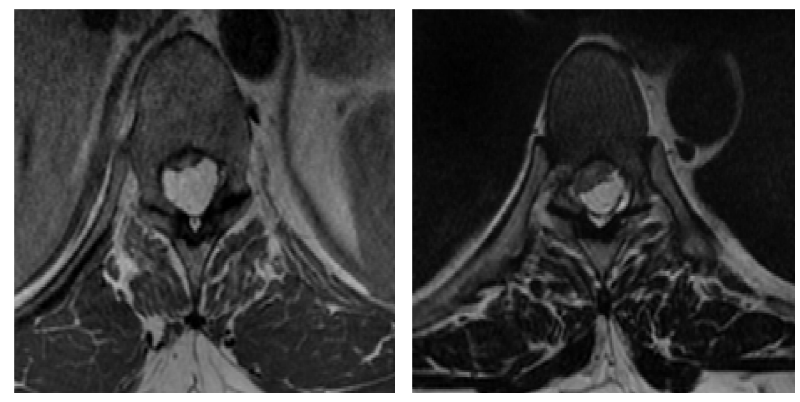

FIGURE 1. Magnetic resonance imaging, T1WImage, dorsal spine sagittal section showing two separate intradural intramedullary lesion at D8-D9 and D10-D12 causing severe distortion of spinal cord with secondary canal stenosis. Vascular component showing hypointense and fatty component with hyperintense signals.

FIGURE 2. Dorsal spine, Magnetic resonance imaging, sagittal section, T2WI showing heterogeneous mass, vascular component showing hyperintense signal on T2-weighted image.

FIGURE 3. Magnetic resonance imaging of dorsal spine, T1Weighted axial section image showing ventrally located angiolipoma.

FIGURE 4. Magnetic resonance imaging of dorsal spine, T2 Weighted image, axial section showing ventrally located angiolipoma with heterogeneous hyperintense signal.

\section{DISCUSSION}

Spinal angiolipoma represents a distinct, benign lesion and characterized by presence of mature fat cells interspersed with excessive abnormal vascular proliferations, commonly observed in the subcutaneous locations. However, spinal angiolipoma represents a separate entity with extremely rare occurrence, predominantly located in the epidural space but extremely rarely can also occur in intradural spinal compartment. Liebscher was credited to first describe the angiolipoma. [10]

Spinal angiolipoma may contain variable proportions of mature adipose tissue interspersed with abnormal vascular elements. The proportion of 
adipose to vascular tissue is variable, being predominantly in lipomatous lesion to the very scanty dense mixed with vascular and stromal elements. [11] Benvenutti-Regato et al. carried out a detailed literature search in 2015 and could find out only a total of 177 patients suffering with spinal epidural angiolipoma. [12] the average age for epidural spinal angiolipoma was 46 years with predlection for female gender [59\%]. The most common presenting symptom was paraparesis (30 $\%$, others were thoracic or low back pain in (24. \%). 12 The majority of epidural spinal angiolipoma occurred, in the order but and least involved site was cervical spine $2.3 \%$. [12]

Histopathologically, ISAL lesions consist of mature adipocytes and network of branching capillary-sized vessels, which usually contain fibrin thrombi and usually positivity for CD31, Factor VIII and Factor XIII a [13].

The clinical feature of ISAL is compressive myelopathy related to spinal cord compression and usually presents early. Case with long standing history may show rapid or acute deterioration as result of enlarging vessels, engorged vein or vascular steal phenomenon, venous thrombosis or occurence of fresh haematoma. [14].

X-ray spine may show enlargement of spinal canal and moulding of adjoining lamina. Angiolipomas typically displays heterogeneous slight hypointense signal compared to typical epidural fat on T1-weighted images and inhomogeneous enhancement on contrast is observed in T1weighted images using fat-saturation techniques. [2, 15]. A high vascular content correlates with the presence of large hypointense regions on T1weighted images. ISALs are typically hyperintense on non-contrast T-1-weighted images relative to other spinal tumors or epidural lipomatosis. [16]. additionally, spinal lipomas occur most commonly in the midline of the lower. [15]

Surgery is the main treatment modalities; however, the extent of surgical resection is variable in reported cases, varying from simple biopsy, and subtotal resection, and near total resection and complete surgical resection have been carried out. Surgical resection may be augmented if surgery is carried out with electro-physiological monitoring. In our case we could only manage with subtotal resection, as this is limitation, as further attempt of resection led to neurophysiological alteration as, we had to stop resection.

Garg et al. reported two cases of ISAL who underwent near total surgical excision.2 Maggi et al. in 1996 reported an eight-year-old female child suffering with D11-L2 intramedullary angiolipoma, who underwent total surgical resection. [7]. Klisch el al. analysed in a 34- year -old female, with intramedullary angiolipoma at C6-D4 level, underwent partial resection and observed the clinical presentation is nonspecific, however, MRI findings was helpful in the preoperative diagnosis and helped in planning of surgical management. [5]. similarly, a 36-year female suffering with C6-D2 intramedullary angiolipoma, also underwent partial surgical resection. [9].

Prasad et al reported a -26-year- female harbouring D5-D9 ISAL, who underwent successful near total surgical excision. [4]. Preul et al. reported a 36-year female with ISAL at D7-D11 underwent only subtotal resection with improved postoperative outcome. [6]. However, Weil et al advised biopsy as treatment modality in a case with large non resectable ISAL, and illustrated a case- 27-year-old female with extensive ISAL at C 5-D8 was managed with surgical biopsy for confirmation of diagnosis. [8].

TABLE 1. Review of Previously reported intradural angiolipoma.

\begin{tabular}{|c|c|c|c|c|c|c|}
\hline S.no. & $\begin{array}{l}\text { Author/ } \\
\text { references }\end{array}$ & Y ear & Age/sex & location & $\begin{array}{l}\text { Surgical } \\
\text { management }\end{array}$ & $\begin{array}{l}\text { Neurological } \\
\text { outcome }\end{array}$ \\
\hline 1 & $\begin{array}{l}\text { Prasad and } \\
\text { Sinha } 4 .\end{array}$ & 2014 & 26 year /male & D5-D9 & Neat total excision & $\begin{array}{l}\text { Incomplete } \\
\text { recovery }\end{array}$ \\
\hline $2 a$ & Garg et. al. ${ }^{2}$ & 2002 & 26 year/male & D3-D7 & Subtotal resection & $\begin{array}{l}\text { Incomplete } \\
\text { recovery }\end{array}$ \\
\hline $\mathrm{b}$ & & 2002 & 28year/male & C6-D2 & subtotal & $\begin{array}{l}\text { Incomplete } \\
\text { recovery }\end{array}$ \\
\hline 3 & Klischet al. ${ }^{5}$ & 1999 & 34 year/ female & C6-D4 & Partial resection & Good outcome \\
\hline 4 & Maggi et al. ${ }^{7}$ & 1996 & 8 year/ female & D11-L2 & total resection & Good outcome \\
\hline
\end{tabular}




\begin{tabular}{|c|c|c|c|c|c|c|}
\hline 5 & Preul et al. ${ }^{6}$ & 1993 & 36 year /female & D7-D11 & subtotal & Good outcome \\
\hline 6 & Weill et al ${ }^{8}$ & 1991 & 27 year/female & C5-D8 & Only biopsy & $\begin{array}{l}\text { No } \\
\text { improvement }\end{array}$ \\
\hline 7 & Palkovic et al. ${ }^{9}$ & 1988 & 27 year/male & C6-D2 & partial & Not available \\
\hline & Current case & 2017 & 48year/male & $\begin{array}{l}\text { D8-D9 and } \\
\text { D10-D12 }\end{array}$ & Subtotal resection & $\begin{array}{l}\text { Incomplete } \\
\text { recovery }\end{array}$ \\
\hline
\end{tabular}

\section{CONCLUSION}

Spinal angiolipoma is a benign lesion and surgery can provide good outcome. Spinal angiolipoma is mostly located in epidural compartment and only eight cases of intramedullary angiolipoma is reported. Preoperative MRI and detailed history and clinical evacuation are helpful in preoperative diagnosis. Current case is extremely rare as two isolated intramedullary angiolipoma were present separately, and underwent successful surgical resection, representing first case- report in the western literature. A high degree of suspicion for spinal angiolipoma should also be kept as differential of intramedullary pathology with typical neuroimaging findings.

\section{REFERENCES}

1. Kujas $M$, Lopes $M$, Lalam TF, et al. Infiltrating extradural spinal angiolipoma. Clin Neuropathol. 1999; 18:93-98.

2. Garg A, Gupta V, Gaikwad S, Deol P, Mishra NK, Sharma MC, et al. Spinal angiolipoma: Report of three cases and review of MRI features. Australas Radiol. 2002; 46:84-90.

3. Fourney DR, Tong KA, Macaulay RJB, et al. Spinal angiolipoma. Spinal angiolipoma occurring intradurally is extremely raer entirty and only eight cases are reported inliterature. CanJ Neu Sci. 2001; 28:82-88.

4. Prasad GL, Sinha S. Spinal intradural subpial angiolipoma: Case report and review of literature. Surg Neurol Int. 2014 Nov 28; 5:164.

5. Klisch J, Spreer J, Bloss HG, Baborie A, Hubbe U. Radiological and histological findings in spinal intramedullary angiolipoma. Neuroradiology. 1999;41:584-7
6. Preul MC, Leblanc R, Tampieri D, Robitaille Y, Pokrupa R. Spinal angiolipomas. Report of three cases. J Neurosurg. 1993;78:280-6.

7. Maggi G, Aliberti F, Colucci MR, Petrone G, Dorato P, De Giorgi AM. Spinal intramedullary angiolipoma. Childs Nerv Syst. 1996; 12:346-9.

8. Weill A, Del Carpio-O'Donovan R, Tampieri D, Melanson D, Ethier R. Spinal angiolipomas: CT and MR aspects. J Comput Assist Tomogr. 1991;15:83-5

9. Palkovic S, Wassmann H, Bonse R, Kashab M. Angiolipoma of the spinal cord. Magnetic resonance imaging and microsurgical management. Surg Neurol. 1988;29:243-5.

10. Liebscher C. Angiolipom des Wirbelkanals mit Kompression des Ruckenmarkes. Prag Med Wochenschr 1901; 26: 18991.

11. Thomas JE, Miller RH. Lipomatous tumors of the spinal canal. A study of their clinical range. Mayo Clin Proc 1973; 48: 393-400

12. Benvenutti-Regato M, De la Garza-Ramos R, Caro-Osorio $E$ . Thoracic epidural spinal angiolipoma with coexisting lumbar spinal stenosis: Case report and review of the literature. Int J Spine Surg. 2015

13. Samdani AF, Garonzik IM, Jallo G, Eberhart CG, Zahos P. Spinal angiolipoma: case report and review of the literature. Acta Neurochir (Wien) 2004 Mar;146(3):299-302

14. Boockvar JA, Black K, Malik S, Stanek A, Tracey KJ. Subacute paraparesis induced by venous thrombosis of a spinal angiolipoma: a case report. Spine. 1997; 22((19)):23042308

15. Choi JY, Goo JM, Chung MJ, Kim HC, Im JG. Angiolipoma of the posterior mediastinum with extension into the spinal canal: a case report. Korean J Radiol. 2000; 1((4)):212-214 